\title{
Pengaruh Mazhab Naḥwu Kūfah dalam Kitab Matn al-Ājurrūmīyah
}

\author{
Andi Holilulloh* \\ Universitas Islam Negeri (UIN) Sunan Kalijaga, Yogyakarta, Indonesia
}

\section{The Influence of the Kūfah School in the Book of Matn al-Äjurrūmīyah}

\section{E-Mail Address}

andiekholilullah@gmail.com

*Corresponding Author

\section{Keywords}

The school of Kūfah; terms of nahwu; al-Äjurrümìyah

\begin{abstract}
The school (madhbab) of Küfah had given a lot of influences on the development of nahwu, including the use of terms. This study uses a qualitative method and the result indicates that there are many terms in the school of Küfah used in the book of al-Ajurrümīyah, including (1) the use of term al-khafd for i'rāb al-ism is written with kasrah, not in the term al-jarr; (2) the use of term al-maf ${ }^{x}$ ul al-ladbi lam yusamma $f \bar{a}$ ' $i l u b$ for the term subject in a passive verb, not using the term ná $i b$ alfáa $i l$; (3) the use of term kayfamā is part of al-af'al al-jawazim or from 'àmil (particle) which can place a fi'l mudāri' into the jussive $\operatorname{mood}(\operatorname{majz} \bar{u} m$ ), as the Küfah scholars believe it; (4) The signs of ism are the entry of alif and lām as believed by the scholars of the Küfah, while according to the scholars of Bașrah it is based on the rules of alif and läm; (5) the use of term al-na't, not al-sifab; (6) al-asmáa' alkhamsah means abüka, akbüka, hamūka, füka, dhū mäl, but the scholars of Bașrah believe that al-asmä' al-sittah is by adding one ism, namely banüka.
\end{abstract}

\section{Pendahuluan}

Sejak berdirinya ilmu nahwu dan selama dinamika perkembangannya, perbedaan pendapat antaraliran ilmu ini sungguh menyita perhatian banyak pihak. Para ahli nạ̣wu (al-nuhāat) berbondong-bondong menampilkan yang terbaik di antara aliran atau mazhab nahwu, di antaranya mazhab nạ̣wu Bașrah, Kūfah, Baghdād, Andalusia, dan Mesir. Kelima mazhab naḥwu ini yang paling diakui keotentikannya oleh para ahli bahasa (linguis) maupun para ahli nahwwu. Namun demikian, tidak sedikit yang berasumsi bahwa hanya mazhab Bașrah dan Kūfah saja yang paling kuat kemurniannya, karena tiga mazhab setelahnya hanya titisan dari dua mazhab nahwu sebelumnya (Dafah, 2006).

Mazhab nahwwu Kūfah sejatinya lebih unggul dari mazhab Baṣrah dalam beberapa aspek, meskipun Kūfah baru lahir setelah 100 tahun eksistensi mazhab Bașrah. Ini dapat dibuktikan dengan karakteristik Kūfah yang sangat deskriptif dalam pemerolehan istilah nậuu. Kūfah meneliti bahasa dengan apa adanya di lingkungan masyarakat Arab, dan tidak mengedepankan pengaruh filsafat 
Yunani yang amat dalam dan menyulitkan. Sementara itu, pemikiran para tokoh klasik mazhab Baṣrah dalam ilmu nạ̣wu, seperti Imam Khaīl ibn Aḥmad al-Farāhīdī, Imam Sībawayh, alMubarrad, dan lainnya, mendapat banyak respon dari berbagai pihak, terutama dalam karya-karya mereka. Tidak sedikit yang menuding bahwa Imam Sībawayh menggunakan pemikiran filsafat Yunani dalam mengembangkan ilmu nahwu sehingga bersifat filosofis-teologis. (Holilulloh, 2020).

Tata bahasa Arab merupakan ilmu yang telah dikuasai oleh para sarjana bahasa Arab selama berabad-abad. Meskipun dikatakan bahwa tata bahasa adalah salah satu ilmu yang telah diselesaikan, mereka yang ahli dalam ilmu tata bahasa terus melanjutkan selama periode yang lama dalam sejarah tata bahasa untuk meninggalkan indikasi kurikulum dan studi mereka. Nahwu menunjukkan pengetahuan Al-Qur'an dan bahasa Arabnya, serta memiliki kontribusi untuk pengembangan studi Islam (Holilulloh \& Ahmad, 2020, p. 18). Sementara itu, dalam sejarah linguistik Arab, banyak tokoh nahwu hebat, seperti pengarang kitab al-Ajurrümīyah yang diyakini sebagai salah satu ulama yang mengembangkan ilmu nahwu yang namanya tidak akan lepas dari sejarah. Ia adalah seorang ulama dan linguis yang berhasil membukukan ilmu nahwu sebagai ilmu yang sangat penting dan banyak dikaji dalam memahami bahasa Arab. Karyanya juga menjadi rujukan utama dalam pembelajaran gramatika Arab (Larhzizer \& Holilulloh, 2020).

Sejauh ini terdapat beberapa kajian ilmiah yang membahas kitab al-Ajurrümīyah. Beberapa di antaranya, yaitu Agung Setiawan (2011), "Ta'līm al-Qawā‘id al-Naḥwìyah bi-al-Kitābayn bayn alĀjurrūmīyah wa-Naẓm al-'Imrīịị: Dirāsah Muqāranah min Nāhiyat Iḥtiwā' al-Mawād wa-Ṭariqat Ta'līmihimā” yang membahas pembelajaran kaidah nahwu dengan membandingkan kitab alAjurrümìyah dan al-'Imrìți yang ditinjau dari segi materi dan metodenya. Penelitian lainnya oleh Muhammad Furqan (2012), "Mafhūm al-Ta'līm al-Qawā'id al-Naḥwīyah bi-al-Kitābayn: alĀjurrūmīyah wa-Naẓm Alfīyah Ibn Mālik: Dirāsah Muqāranah min Haythu al-Mawādd wa-alTarīqah” yang membahas pembelajaran kaidah nahwu dengan membandingkan kitab alÄjurrūmìyah dan Alfìyab Ibn Mālik ditinjau dari segi materi dan metodenya. Kemudian, Mu'azziz (2012), "Mushkilat Ta 'līm al-Qawā'id al-Naḥwìyah fī Madrasah al-Nawāwī al-Dīnīyah bi-Ma'had alFițrah al-Islāmī Jejeran: Dirāsah Taḥlīlīyah 'an al-Ṭarīqah” yang mengkaji kesulitan pembelajaran tata bahasa dalam ilmu nahwu di Sekolah Diniyah Jejeran ditinjau dari aspek analisis metodenya. Terakhir, Abu Said (2019), "Problematika Pembelajaran Nahwu Dengan Menggunakan Kitab alAjurrumiyyah Jawan Kelas Satu Pondok Pesantren Darul Abror Watumas Purwokerto Utara” yang meneliti tentang problematika pembelajaran nahwu dengan kitab al-Ajjurrümīyah di pesantren Darul Abror, Purwokerto.

Berbeda dengan penelitian sebelumnya, penelitian ini lebih fokus pada dominasi mazhab nahwu Kūfah dalam kitab al-Ajjurrümīyah yang secara kebetulan atau tidak, memiliki daya tarik yang berbeda. Kitab ini tampak menarik untuk dikaji lebih jauh karena memiliki kekhususan dan karakteristik yang kuat dalam kandungan materinya. Oleh karena itu, penulis mengangkat tema tentang pengaruh mazhab nahwwu Kūfah dalam kitab al-Ajjurrümīyah dengan menggunakan pendekatan historis. Tema ini memiliki nilai lebih dan menjadi sesuatu hal yang baru dalam keilmuan bahasa Arab. Selain itu, juga dapat menjadi alternatif jawaban dari persoalan bagaimana pengaruh mazhab nạwwu Kūfah dalam kitab tersebut, dan mengapa Ibn Ājurrūm begitu terpengaruh dengan mazhab nạwu Kūfah. 


\section{Metode Penelitian}

Tulisan ini merupakan studi kepustakaan (library research) yang menganalisis pengaruh mazhab naḥwu Kūfah dalam pemikiran Ibn Ājurrūm dalam kitabnya al-Ajjurrūmīyah. Adapun metode yang digunakan adalah metode kualitatif dengan pendekatan sejarah (historis) untuk menghasilkan data deskriptif berupa kata-kata tertulis dari buku-buku yang berkaitan dengan masalah penelitian. Sementara itu, langkah-langkah yang digunakan dalam penelitian ini, yaitu: (1) membaca kitab alAjurrūmīyah dan kitab-kitab tentang sejarah ilmu nạ̣wu (tārīkh al-naḅw), selain juga kitab-kitab lainnya yang relevan dengan penelitian ini; (2) mengidentifikasi data penelitian; (3) menganalisis karakteristik setiap data penelitian; (4) menentukan karakteristik bahan dan data dengan beberapa teori dan penelitian sebelumnya; (5) mendeskripsikan data temuan; (6) menyimpulkan hasil berdasarkan temuan data. Terakhir, teknik analisis data yang digunakan dalam penelitian ini mengikuti perspektif Tammām Ḥassān, yaitu menganalisis materi nạ̣wu dapat dilakukan dengan cara induktif atau deduktif dalam sistematika penyajiannya (Hassān, 2000).

\section{Hasil Penelitian dan Pembahasan}

\section{A. Kilas Mazhab Naḥwu Kūfah}

Ilmu nahwu mazhab Kūfah hadir dan berkembang karena peran serta dan pengaruh yang besar dari mazhab Bașrah. Mazhab Kūfah didirikan sekitar satu abad setelah munculnya mazhab Baṣrah di mana ilmu nahwu ini sejatinya sangat berhubungan dengan tempat, suku, dan kehidupan yang ada di dalamnya (Mu'minin, 2008). Dilihat dari sisi geografis, Kūfah merupakan jalur perdagangan dan tempat pergantian kebudayaan. Karakter kehidupan mazhab Kūfah adalah militer, dan sebagian dari mereka adalah para imigran yang ahli dalam qirā’ah, fikih, dan syair. Dari 7 ahli qirā’ah yang terkenal, mazhab Kūfah memiliki 3 di antaranya, yaitu An'im ibn Abī al-Nujūd, Hamzah ibn Abī al-Ziyād, dan Hamzah al-Kisā’̂̄. Mereka ini adalah para ahli qirā’ah Al-Qur’an, selain juga ahli dalam bidang hadis dan ușūl al-fiqh (Wahyudi, 2015).

Di saat para intelektual mazhab Bașrah sedang mengalami masa kemunduran dalam kajian bahasa dan nậwu, mazhab Kūfah justru sebaliknya, bergeliat dalam pengembangan kajian agama Islam, periwayatan syair dan sastra. Pada saat itu pula, muncul nama al-Kisā’̄i sebagai tokoh penting dalam lahirnya mazhab nạ̣wu Kūfah yang juga kemudian dikembangkan oleh muridnya, Yahyá ibn Ziyād al-Farrā'. Kūfah mampu berjaya dan berkembang pesat sampai masa Ibn Ājurrūm yang kemudian menulis kitab al-Ajurrümīyah. Karena itu pula, kitab ini lebih tepat dikategorisasikan sebagai kitab yang menganut mazhab Kūfah (Ibn Hanīyah, 2009).

Terdapat lima generasi ulama-ulama yang secara turun-temurun meneruskan perjuangan mazhab Kūfah, yaitu seperti yang terdapat dalam tabel berikut (Dayf, 1976).

Tabel 1. Periodisasi generasi ulama mazhab Kūfah

\begin{tabular}{|c|c|c|c|c|}
\hline No & Periodisasi & Nama Tokoh & Nama Asli & Wafat \\
\hline 1 & Pertama & $\begin{array}{l}\text { Mu'ādh al-Farrā'ī } \\
\text { al-Ru'āsī }\end{array}$ & $\begin{array}{l}\text { Abū Muslim Mu'ādh ibn } \\
\text { Muslim al-Farrā'̄ī } \\
\text { Abū Ja'far Muḥammad ibn al- } \\
\text { Hasan ibn Abī Sārah }\end{array}$ & $\begin{array}{l}\text { Tidak } \\
\text { diketahui }\end{array}$ \\
\hline 2 & Kedua & al-Kisā'̄ī & Abū Ḥasan 'Alī ibn Hamzah & $189 \mathrm{H}$ \\
\hline 3 & Ketiga & al-Amar & Tidak diketahui & $194 \mathrm{H}$ \\
\hline
\end{tabular}




\begin{tabular}{|c|c|c|c|c|}
\hline & & al-Liḥyānī & $\begin{array}{l}\text { Abū al-Hasan 'Alīi ibn al- } \\
\text { Mubārak }\end{array}$ & $220 \mathrm{H}$ \\
\hline & & al-Farrā' & Tidak diketahui & $207 \mathrm{H}$ \\
\hline & & Hishām al-Ḍarīr & $\begin{array}{l}\text { Abū 'Abd Allāh Hishām ibn } \\
\text { Mu'āwiyah }\end{array}$ & $209 \mathrm{H}$ \\
\hline & & Ibn Sa'dān & $\begin{array}{l}\text { Abū Ja'far Muhammad ibn } \\
\text { Sa'dān }\end{array}$ & $231 \mathrm{H}$ \\
\hline & Keempat & al-Huwāl & Tidak diketahui & $234 \mathrm{H}$ \\
\hline & & Ibn Qadīm & Tidak diketahui & $251 \mathrm{H}$ \\
\hline 5 & Kelima & Tha'lab & $\begin{array}{l}\text { Abū al-'Abbās Aḥmad ibn } \\
\text { Yahyá ibn Zayd ibn Sayyār }\end{array}$ & $291 \mathrm{H}$ \\
\hline
\end{tabular}

\section{B. Biografi Ibn Ājurrūm}

Ibn Ājurrūm, nama aslinya Abū 'Abd Allāh Muḥammad ibn 'Abd Allāh ibn Dāwud al-Ṣanhājī, lahir di kota Fez, Maroko (Maghrib), pada tahun $672 \mathrm{H}$. Terdapat perbedaan pendapat di kalangan ulama tentang tahun kelahirannya ini. Hàjīi Khalīfah, pengarang kitab Kashf al-Zunūn 'an Asāmì al-Kutub wa-al-Funūn berpendapat bahwa Ibn Ājurrūm lahir pada tahun $682 \mathrm{H}$ (Khalīfah, n-d., p. 1796) Imam Halawī lebih meyakini-seperti yang tertuang dalam karyanya Sharh al-Ajurrümīyah-bahwa Ibn Ājurrūm lahir pada tahun $672 \mathrm{H}$. Sementara itu, dalam kitab Salwat al-Anfās wa-Muhadathat al-Akyās bi-Man Uqbira min al-'Ulamā' wa-al-Sulaḥā' bi-Fās karya al-Kattānī disebutkan bahwa tahun kelahiran Ibn Ājurrūm tepat ketika Imam Ibn Mālik, pengarang kitab Nazm Alfíyah, wafat (al-Kattān̄i, 2004, p. 126-128) Ibn Ājurrūm wafat pada10 Safar tahun 723 H dalam usia 51 tahun, dan dimakamkan di Bāb al-Jizyīn, kota Fez, Maroko (Wajdī, 1971).

Ibn Ājurrūm memulai langkah awal belajar ilmu nahwu di kota kelahirannya, Fez. Setelah itu, ia belajar ke Mekah sambil melaksanakan haji, dan juga belajar ke kota Kairo, Mesir. Belum banyak pembahasan mengenai siapa guru Ibn Ājurrūm. Namun, terdapat riwayat yang menjelaskan bahwa guru Ibn Ājurrūm adalah Abū Hayyān Muhammad ibn Yūsuf al-Gharnāṭī. Pernyataan ini juga diamini oleh Ibn al-Hāj dalam kitab Hēāhiyah atas kitab Sharh al-Ājurrūmīyah bahwa Ibn Ājurrūm memiliki beberapa guru, di antaranya yaitu Abū Ḥayyān. Ibn Ājurrūm ketika melaksanakan ibadah haji, pada saat itu beliau melewati kota Kairo, Mesir. Di kota inilah kemudian belajar Abū Hayyān, seorang ulama nabwu yang sangat terkenal yang berasal dari Küfah yang wafat di Kairo pada tahun $745 \mathrm{H} / 1345 \mathrm{M}$ (Holilulloh, 2019).

Selain guru, Ibn Ājurrūm juga memiliki beberapa murid. Banyak dari penduduk kota Fez yang belajar berbagai bidang ilmu, termasuk ilmu nạ̣wu, kepada Ibn Ājurrūm, seperti Syekh Abī al'Abbās Aḥmad ibn Muḥammad 'Abd Allāh ibn 'Umar al-Ghassānī al-Naḥwī dan al-Ustādh alMaghribī Abī al-'Abbās Aḥmad ibn Muhammad 'Abd Allāh ibn Ḥizbullāh (al-Kattānī, 2004). Imam al-Suyūṭi dalam kitabnya Bughyat al-Wu'àt fì Tabaqāt al-Lughawiyin wa-al-Nuhāt mengatakan, "saya tidak berhenti menerjemahkan karyanya Ibn Ājurrūm, kecuali saya melihat dalam sejarah Gharnātah (Granada) dalam biografi (tarjamah) Muhammad ibn 'Alī ibn 'Umar al-Ghassānī alNahwī. Sungguh ia telah belajar banyak kepada Ibn Ājurrūm di kota Fez (al-Suyūṭī, 1969, p. 238239). Berikut ini beberapa murid dari Ibn Ājurrūm.

1. Aḥmad ibn Muḥammad ibn Hizbullāh al-Khazrajī, seorang alim dan ustaz. Beliau wafat pada tahun 741 H (al-Qāẹīi, 1973). 
2. Muhạmmad ibn Aḥmad 'Alīibn 'Umar ibn Yahyá al-Ghassānī Abū 'Abdillāh (682-742 H), beliau merupakan pakar dan ahli dalam bidang ilmu agama dan lain-lain.

3. Aḥmad ibn Muḥammad ibn Shu'ayb al-Juzna, dari penduduk kota Fez. Dikenal juga dengan sebutan, Abū al-'Abbās, Ibn Shu'ayb, dan juga Jaznānah (sebutan untuk kelompok dari kaum Barbar). Ia merupakan ulama yang berasal dari bagian barat dan dikenal ahli dalam bidang írāb, hafal berbagai syair, serta ahli dalam bidang filsafat dan kimia. Tidak hanya itu, Ahmad ibn Muhammad ibn Shu'ayb juga memiliki kemampuan dalam syair yang tinggi dan karya tulisan yang baik. Ia juga mempunyai banyak guru di kota Fas, di antaranya Abū 'Abdillāh ibn Ibn Ājurrūm yang wafat di Tunisia pada tahun $749 \mathrm{H}$.

4. 'Abdullāh al-Wa'îlī al-Ḍarīr Abū Muhammad, ia lahir di kota Fez, belajar banyak tentang fikih, dan wafat pada tahun $779 \mathrm{H}$.

\section{Pengaruh Mazhab Kūfah dalam Kitab al-Äjurrūmīyah}

Sebagaimana telah dijelaskan sebelumnya, Ibn Ājurrūm banyak belajar dari Abū Ḥayyān Athīr alDīn al-Gharnāṭ̂̄ mengenai ilmu naḥwu. Abū Hayyān lahir pada tahun 654 H/1256 M di Granada, Spanyol. Ia merupakan salah satu ulama nạwwu dan juga ahli tafsir (mufassir) Al-Qur'an yang dikenal luas pada masa itu. Ia juga pengarang dari kitab al-Baḥr al-Mubịt (Salim, 1999). Abū Hayyān merupakan seorang penganut mazhab fikih al-Ẓāhirī yang banyak dipengaruhi oleh pemikiran Ibn Maḍā’ al-Qurțūbī yang berasal dari Andalusia. Kemudian, Abū Hayyān menjadi guru yang berperan penting bagi Ibn Ājurrūm di mana ia mendapat ijazah darinya (al-Sanhūrī, 2006).

Ibn Ājurrūm dikenal sebagai ulama nahwwu bermazhab Kūfah. Hal ini dapat dilihat dari beberapa penggunaan terminologi ilmu nahwu dalam karyanya yang menjadi ciri khas mazhab Kūfah. Berikut ini adalah beberapa penggunaan istilah nạwu bercorak mazhab Kūfah yang digunakan oleh Ibn Ājurrūm (al-Sanhūrī, 2006).

1. Ibn Ājurrūm menyebutkan harakat kasrah dengan istilah al-khafd, sedangkan mazhab Bașrah menggunakan istilah al-jarr.

2. Dalam istilah na'ib al-fail, Ibn Ājurrūm menggunakan istilah al-maf'ül al-ladhī lam yusamma failuh.

3. Ibn Ājurrūm memiliki pendapat bahwa fì l amr itu hukumnya jazm sebagaimana pendapat mazhab Kūfah. Sementara itu, mazhab Bașrah memiliki pendapat bahwa fi l amritu hukumnya mabnì 'alá al-sukūn.

4. Ibn Ājurrūm meyakini bahwa istilah kayfamā adalah bagian dari al-af'āl al-jawāzim atau dari 'àmil yang men-jazm-kan fìl mudạri' sebagaimana mazhab Kūfah meyakininya. Namun, mazhab Baṣrah menyangkal hal tersebut.

5. Ibn Ājurrūm mengatakan bahwa di antara tanda-tanda ism adalah masuknya alif dan lām sebagaimana yang diyakini oleh ulama mazhab Kūfah. Sementara itu, menurut ulama Baṣrah itu berdasarkan kaidah alif dan lām.

6. Menurut Ibn Ājurrūm, secara istilah disebutkan bahwasanya al-asmā' al-khamsah itu lafaznya

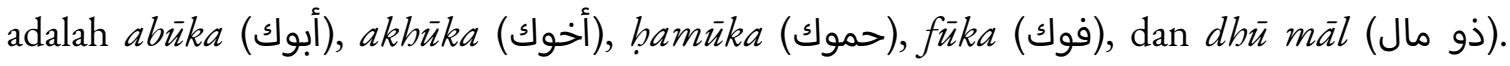
Namun, menurut ulama mazhab Baṣrah, itu adalah al-asmä’ al-sittah, yakni dengan menambahkan satu ism, yaitu banūka (هنوك). 
Demikianlah sebagian indikasi yang menunjukan bahwasanya Ibn Ājurrūm itu mengikuti ulama mazhab Kūfah.

\section{Istilah-istilah Naḥwu Mazhab Kūfah dalam Kitab al-Ajurrümīyah}

Kitab ini dikenal dengan nama kitab al-Ajurrümìyah, sesuai dengan nama pengarangnya yang bernama Ibn Ājurrūm. Sebagaimana diketahui bahwa kitab ini merupakan salah satu dari kitab kaidah tata bahasa Arab (qawā'id al-lughah al-'Árabiyab) yang menjadi rujukan penting dalam mempelajari ilmu nahwu. Kitab ini juga dikenal dengan nama Matn al-Ajjurrümīyah karena kandungan materi yang ada di dalamnya disajikan dalam bentuk teks-teks, bukan bait-bait (nazm) seperti halnya kitab Nazm Alfíyah, al-'Imrītīi, dan kitab-kitab nahwu lainnya. Kitab al-Ajurrumīyah ini berisi materi ilmu nahwu yang bersifat dasar. Materi kitab disajikan secara sederhana dan diperuntukan bagi pemerhati bahasa Arab, khususnya pemula (mubtadi`in). Selain itu, kitab ini juga tidak terlalu tebal, namun materinya lengkap sehingga banyak menjadi rujukan bagi pembelajar bahasa Arab. Sementara itu, dalam penyajian materinya, kitab al-Äjurrümīyah ini menggunakan metode deduktif (al-țariqah al-qiyāsizyah), yaitu metode yang menggunakan pengertian istilah dan penjelasan mengenai suatu materi, kemudian diakhiri dengan contoh kalimatnya. Inti dari metode ini adalah, pembelajaran nahwu dimulai dengan penyajian kaidah-kadiah terlebih dahulu, kemudian diikuti dengan contoh-contoh yang dapat memperjelas kaidah yang telah dipelajari (Mīdānī, 2009).

Ibn Ājurrūm menulis kitab ini pada tahun 719 H, empat tahun sebelum beliau wafat. Saat itu, juga ada ulama bernama Ibn Maktūm yang satu masa dengan Ibn Ājurrūm. Ia menyebutkan bahwa Ibn Ājurrūm memujinya dan menulis kitab al-Ajurrūmīyah. Imam Hāmid juga menambahkan, Ibn $\bar{A}$ jurrūm menulis kitab ini dalam keadaan terpaksa dan saat perasaan hatinya sedang tidak baik. Dengan sifat warak dan tawakal yang dimiliki oleh Ibn Ājurrūm, kitab al-Ajjurrümīyah ini ia tulis sampai selesai saat sedang berada di Mekah, tepatnya di depan Ka’bah (Khūrshīd, 1975).

Dalam riwayat lain juga dijelaskan bahwa setelah Ibn Ājurrūm mengarang kitab al-Äjurrūmīyah ini dan menyempurnakannya, ia kemudian menuju ke laut. Kemudian ia berazam untuk menenggelamkan kitab tersebut ke dalam air yang mengalir, sambil berkata: "Jika memang saya ikhlas mengarang kitab al-Ajurrümīyah ini karena Allah Swt., maka kitab ini tidak akan luntur meskipun diterpa ombak air laut, dan kitab ini akan memberikan manfaat bagi manusia”. Ketika diletakkan di dalam air, kitab al-Ajurrümīyah itu pun tetap utuh dan tintanya tidak luntur sedikit pun (Holilulloh, 2019).

Kitab al-Ajurrümiyah terdiri atas 25 bāb dan satu fașl. Faṣl merupakan lanjutan atau tambahan materi pada bab sebelumnya, yakni bāb ma'rifat 'alāmat al-i'rāb yang masih membahas seputar tanda i $r \bar{r} \bar{b}$ yang terdapat dalam suatu kata. Bab pertama dalam kitab al-Ajurrümīyah ini diawali dengan bāb al-kalām yang menjelaskan seputar pembagian jenis kata (kalimah) beserta keterangan pendukungnya, pembagian huruf jarr dan tanda-tanda kata pada $f_{i} l$, ism, dan ḅurüf. Kemudian diteruskan dengan pembahasan tentang $b \bar{a} b$ al-i'rāb, bāb ma'rifat 'alāmat al-i'rāa bașl al-mu'rabāt yang membahas tentang i'rāb suatu lafaz berbahasa Arab, seperti i'rāb rafa', naṣb, khafḍ, dan jazm. Selain itu, juga menjelaskan keadaan i'rāb beserta tanda-tandanya dan penjelasan mengenai penempatan tanda i $r \bar{r} \bar{b}$.

$B \bar{a} b$ al-af'āl menjelaskan pembagian fi ${ }^{\prime} l$ menurut ilmu nậu, $F i ' l$ terbagi menjadi tiga, yaitu

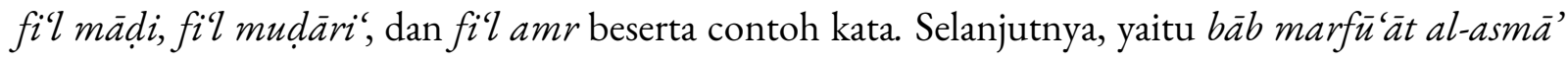


yang berkaitan dengan bab selanjutnya, yaitu $b \bar{a} b$ al-fá'il, bāb al-maf'ūl al-ladbì lam yusamma fä'ilub, bāb al-mubtadā' wa-al-khabar, dan bāb al-'awāmil al-dākhilab 'alá al-mubtadā' wa-alkhabar. Untuk bāb al-na't, bāb al-'atf, bāb al-tawkìd, bāb al-badal menjelaskan tentang macammacam pengikut dari segi i'rāb rafa', naṣb, khafd, dan jazm.

Untuk bāb manșūbāt al-asmā' membahas ism-ism yang dibaca nașab, yang pada bab selanjutnya juga dijelaskan lebih rinci pembagiannya menjadi bāb al-maf'ūl bih, bāb al-mașdar, bāb al-zarf al-zamān wa-al-zarf al-makān, bāb al-hāl, bab al-tamyīz, bāb al-istithnā', bāb lā, bab almunādá, bab al-maf'ūl min ajlih, dan bāb al-maf'ül ma'ah. Sementara itu, untuk bab yang terakhir adalah $b \bar{a} b$ makhfüdāt al-asm $\bar{a}$. Bab ini membahas tentang sebab apa saja yang menjadikan ism-ism dibaca khafd, serta menjelaskan huruf-huruf apa saja yang dapat menyebabkan kata ism dibaca khafd.

Kitab al-Äjurrümīyah jika ditinjau dari sistematika penyajiannya, cenderung lebih kepada kajian naḥwu dengan menggunakan metode deduktif (al-țaīqah al-qiyāsīyah), yaitu metode penyajian dengan menampilkan pengertian dan penjelasan terlebih dahulu, kemudian diikuti oleh contoh-contoh kalimat sebagai pelengkap dalam penjelasannya. Dalam kitab al-Äjurrümīyah, secara nyata dan jelas memang tidak disebutkan bahwa kitab ini merupakan kitab bermazhab Kūfah. Namun, jika dianalisa dari isi kitab tersebut, pengarangnya yang bernama Ibn Ājurrūm adalah murid dari Abū Hayyān yang bermazhab Kūfah. Ini juga tampak pada istilah-istilah nạ̣wu yang digunakan dalam kitab al-Ajurrümīyah. Banyak sekali penggunaan istilah mazhab Kūfah yang digunakan oleh Ibn Ājurrūm dalam kitabnya (al-Șanhājīi, 1998). Oleh sebab itu, penulis merasa perlu menampilkan istilah-istilah yang digunakan mazhab Kūfah ke dalam bentuk tabel berikut ini sehingga pembaca mampu mengenal istilah-istilah nạ̣wu mazhab Kūfah yang digunakan dalam kitab al-Ajurrümīyah.

Tabel 2. Istilah-istilah naḥwu mazhab Kūfah dalam kitab al-Ājurrūmīyah

\begin{tabular}{|c|c|c|}
\hline \multirow{2}{*}{ No } & \multicolumn{2}{|c|}{ Istilah-istilah nahwu } \\
\hline & Mazhab Kūfah & Dalam Kitab al-Ajurrümìyah \\
\hline 1 & المفعول اللّي لم يسمّ فاعله & المفعول الّذي لم يسمّ فاعله \\
\hline 2 & القطع & 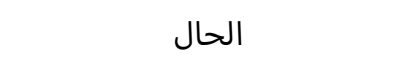 \\
\hline 3 & 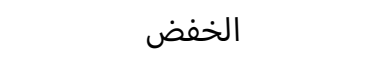 & 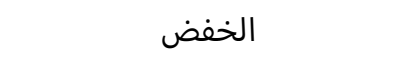 \\
\hline 4 & (المرافع) عند الفرّاء & الخبر \\
\hline 5 & (المثال) عند ثعلب & 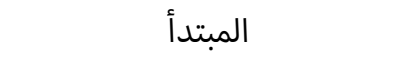 \\
\hline 6 & أشباه المفاعيل & الظرف الزمان والظرف المكان \\
\hline 7 & أشباه المفاعيل & المصدر \\
\hline 8 & أشباه المفاعيل & المفعول لأجله \\
\hline 9 & أشباه المفاعيل & المفعول معه \\
\hline 10 & العطف & 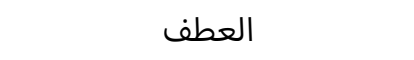 \\
\hline 11 & الخفض & 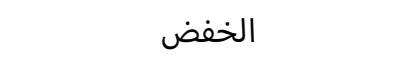 \\
\hline 12 & التفسير & التمييز \\
\hline 13 & الفعل الدائم & إسم الفاعل \\
\hline 14 & المكني والكناية & الضمير \\
\hline 15 & عطف النسق & Tidak dipakai \\
\hline 16 & حروف الجحد & Tidak dipakai \\
\hline
\end{tabular}




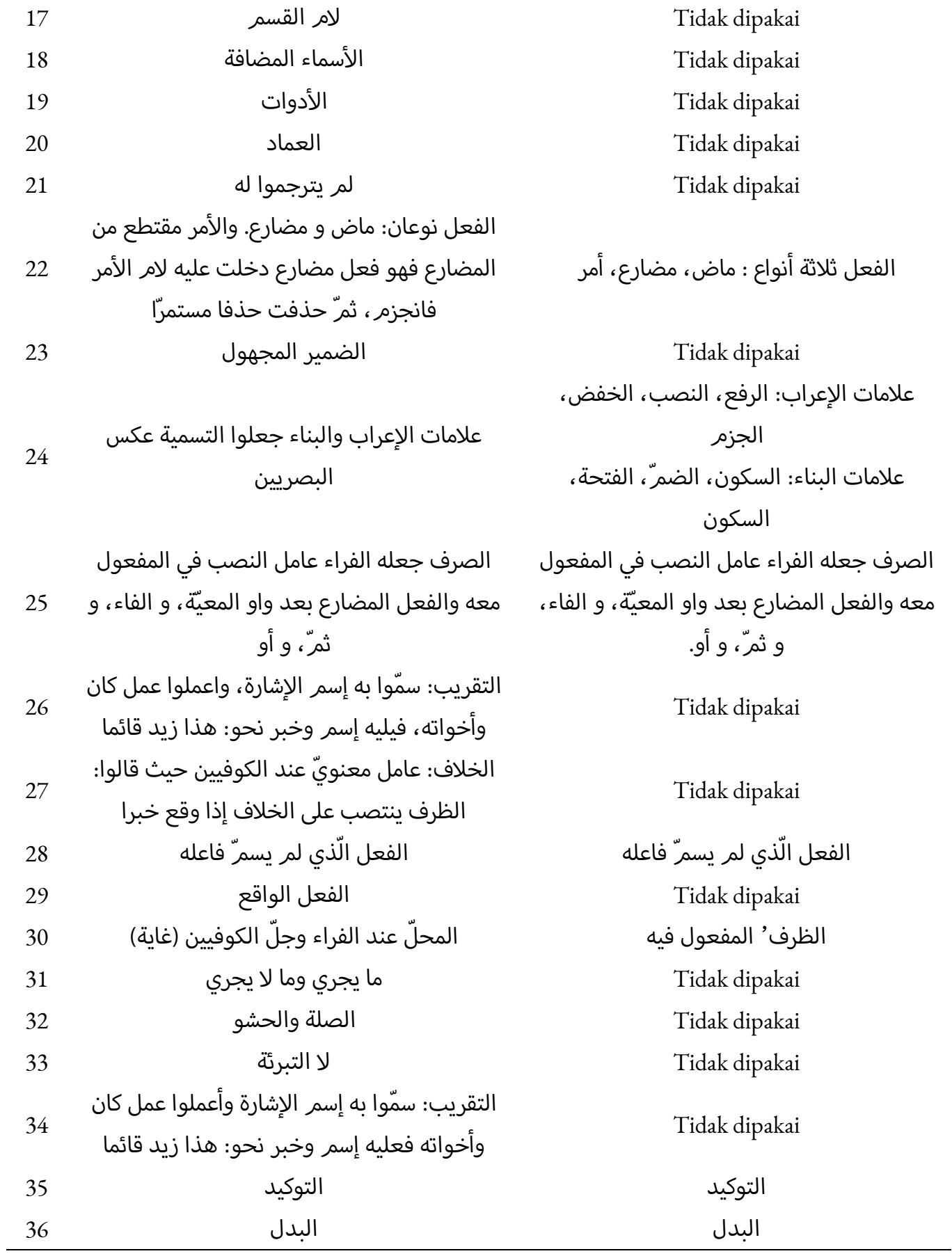

\section{E. Tujuan dan Manfaat Kitab al-Ajjurrümīyah}

Kitab al-Ajurrümīyah merupakan kitab dasar dalam ilmu nabwu di mana pengarangnya, Ibn alÂjurrūm, menulis kitab ini bertujuan untuk mendekatkan kepada pembelajar bahasa Arab dan untuk memudahkan kepada para pemula untuk menghafalnya. Selain itu, juga sebagai wasilah untuk memahami ilmu nabwu ke tahap yang lebih tinggi (al-'Imrīți, 2009). Kitab ini juga merupakan salah satu kitab yang digunakan oleh pemerhati bahasa Arab di beberapa pesantren dan sekolah agama Islam lainnya, khususnya di pesantren-pesantren salafi. Kitab ini telah digunakan di umumnya pondok pesantren sejak zaman dahulu hingga zaman sekarang. Meskipun terlihat ringkas, 
kandungan kitab al-Äjurrümīyah dipenuhi dengan materi yang komprehensif sehingga menjadikan kitab ini sangat populer.

\section{Simpulan}

Beberapa penggunaan istilah naḥwu dalam kitab al-Ajurrümiyah cenderung merujuk pada istilahistilah yang digunakan oleh mazhab Kūfah. Ini disebabkan karena latar belakang pengarangnya, Ibn $\bar{A}$ jurrūm, sehingga berpengaruh dalam karyanya. Dominannya penggunaan istilah-istilah nạwu mazhab Kūfah ini dalam kitab al-Ajurrümīyah dapat dibuktikan antara lain, (1) penggunaan istilah al-khaf̣ untuk i'rāb al-ism yang berharakat kasrah, bukan dengan istilah al-jarr; (2) penggunaan istilah al-maf'ül al-ladbì lam yusamma fá'ilub untuk istilah subjek dalam kata kerja pasif, tidak menggunakan istilah ná̀ib al-fácil; (3) penggunaan istilah kayfamā sebagai bagian dari al-af'āl aljawāzim atau dari 'ámil yang men-jazm-kan fi' l mudāri' sebagaimana mazhab Kūfah meyakininya; (4) tanda-tanda ism yaitu dimasuki alif dan làm sebagaimana yang diyakini oleh ulama mazhab Kūfah, sedangkan menurut ulama Baṣrah itu berdasarkan kaidah alif dan lām; (5) penggunaan istilah al-na't tidak dengan istilah al-sifab; (6) al-asmä' al-khamsah terdiri dari abüka, akbüka, bamūka, füka, dbū mäl. Namun, ulama mazhab Bașrah menggunakan istilah al-asmā' al-sittah, dengan menambahkan satu ism yakni hanūka.

\section{Daftar Rujukan}

Dafah, B. (2006). al-Naḥwu al-'Arabīyah bayn al-taqlīd wa-al-manāhij al-lisānīyah al-ḥadīthah. alAthar, 5(5), 63-75. Retrieved from https://www.asjp.cerist.dz/en/article/50844

Ḍayf, Sh. (1976). al-Madāris al-naḥwīyah (5 $5^{\text {th }}$., Ed.) Cairo: Dār al-Ma'ārif.

Hassan, T. (2000). al-Khulāṣah al-nạ̣wīyah. Cairo: 'Ālam al-Kutub.

Holilulloh, A. Ibn Ajurrüm wa-afkārub fì ta lìm al-naḅwi. Yogyakarta: Trussmedia Grafika, 2019.

Holilulloh, A. (2020). Kontribusi pemikiran nahwu Imam Sibawaih dan Ibrahim Mushtafa dalam linguistik Arab. Alfaz (Arabic Literatures for Academic Zealots), 8(1), 35-56. Doi:10.32678/alfaz.Vol8.Iss1.2448

Holilulloh, A. \& Ahmad, A. M. (2020). Taysīr ta'allum al-lughah al-'Arabīyah wa-al-dirāsāt alIslāmīyah 'inda al-lughawīyīn al-hadīthīn. Imtiyaz: Jurnal Pendidikan Babasa Arab, 4(1), 118. doi:10.29300/im.v4i1.3224

Holilulloh, A. \& Larhzizer, F. (2020). Makānat al-lughah al-'Arabīyah fī Indūnīsiyā. Tsaqofiya: Jurnal Pendidikan Bahasa dan Sastra Arab, 2(2), 148-159. Doi:10.21154/tsaqofiya.v2i2.30

Ibn Hanīyah, 'A. 'A. (2009). al-Madrasah al-Maghribìah fì al-nabwi al-'Arabì: Matan alAjurrūmīyah 'ayyinah (Master's thesis, Jāmi' at Qaṣdī Mirbāḥ, Ouragla, Algeria).

al-'Imrīṭi. Sh. Y. (2009). al-Durrat al-bahìyah nazm al-Äjurrūmīyah. Giza: Maktabat Awlād alShaykh li-al-Turāth.

Khalīfah, H.. (n-d.). Kashf al-zunūn 'an asāmī al-kutub wa-al-funūn (Vol. 2). Beirut: Dār Ihyā' li-alTurāth al-'Arabī.

Khūrshīd, I. Z . (1975). Dāirat al-ma'ārif al-Islāmīyah. Cairo: Dār al-Sha'b.

al-Kattānī. (2004). Salwat al-anfās wa-muhādathat al-akyās bi-man uqbira min al-ulamä'wa-alsulaḥā'bi-Fās. Casablanca: Dār al-Thaqāfah. 
Mu'azziz. (2009). Mushkilat ta'līm qawāid al-naḅwī Fi madrasah al-Nawāwì al-dinnīyab biMa'had al-Fitrah al-Islämi Jejeran (Skripsi, UIN Sunan Kalijaga Yogyakarta). Retrieved from http://digilib.uin-suka.ac.id/2942/

Mu'minin, I. S. (2008). Kamus Ilmu Nabwu E'Sharaf. Jakarta: Amzah.

Mīdānī, I. H.. (2009) Wāqi' al-naḥw al-ta'īimī al-'Arabī bayn al-ḥājah al-tarbawīyah wa-ta'qīid alzamān. Majallat Kullìyah al-Adab wa-al-'Ulūm al-Insānìyah wa-al-Ijtimāì̄yah, 5.

al-Qādịî, A. (1973). Jadhwat al-iqtibās fì man ḥalla min al-a 'lām madinat Fās. Rabat: Dār alManșūr li-al-Ṭibā'ah wa-al-Warrāqah.

Said, Abu. (2019). Problematika Pembelajaran Nabwu Dengan Menggunakan Kitab alAjurrumiyyah Jawan Kelas Satu Pondok Pesantren Darul Abror Watumas Purwokerto Utara (Skripsi, IAIN Purwokerto). Retrieved from http://repository.iainpurwokerto.ac.id/5460/

Salīm, S. 'A. (1999). Tārīkh al-Maghrib fi al-'aṣr al-Islāmi. Alexandria: Jāmi'ah al-Iskandārīyah.

Setiawan, A. (2012). Ta lìm al-qawā'id al-na h̦wìah bi-al-kitābayn bayn al-Äjurrümīyah wa-Nazm al-Imrịtīi: Dirāsah muqāranah min nāḥiyat iḥtiwā' al-mawādd wa-țariqat ta 'ìmihimā (Skripsi, UIN Sunan Kalijaga, Yogyakarta).

al-Sanhūrī, 'A. (2006). Sharh al-Ājurrūmìyah fì' 'ilm al-Arabìyah. Cairo: Dār al-Salām.

al-Ṣanhājī. (1998). Matn al-Ajurrumiyyah. Riyadh: Dār al-Ṣamīīi.

al-Suyūṭī. (n-d.). Bughyat al-wu'āt fì țabaqāt al-lughawīyìn wa-al-nuhāat. Cairo: Maṭba'at 'İsá alBābī al-Hạabī wa-Shurakāh.

Wajdī. M. F. (1971). Dā'irat al-ma'ārif al-qarn al-ǐishrīn. Beirut: Dār al-Ma'rifah.

Wahyudi, F. (2015). Kisah Balik Sejarah Pendidikan Babasa Arab di Nusantara dan Mancanegara. Yogyakarta: Sunris. 